\title{
Leadership and Motivation to Performance through Job Satisfaction of Hotel Employees at D'Merlion Batam
}

\author{
Yandra Rivaldo* \\ Business Management Department, Institut Agama Islam Abdullah Said Batam \\ J1. R Soeprapto RT 002 RW XI, Batu Aji, Kota Batam 29422, Indonesia \\ yandraa.rivaldo@gmail.com
}

Received: 02 ${ }^{\text {nd }}$ February 2021/ Revised: 07 ${ }^{\text {th }}$ March 2021/ Accepted: $12^{\text {th }}$ March 2021

\begin{abstract}
How to Cite: Rivaldo, Y. (2021). Leadership and motivation to performance through job satisfaction of hotel employees at D'Merlion Batam. The Winners, 22(1), 25-30.

https://doi.org/10.21512/tw.v22i1.7039
\end{abstract}

\begin{abstract}
The research aimed to confirm the theory with empirical evidence focusing on leadership, employee motivation, employee job satisfaction, and employee performance. The research applied a causal model survey method with path analysis techniques. The population were 45 employees of the D'Merlion Hotel Batam, and the sample was taken by using a census method. The significance value of leadership on job satisfaction is $0,082>0,05$, it is concluded that direct leadership has no significant effect on job satisfaction. The significance value of motivation on job satisfaction is $0,000<0,05$, which implies that motivation has a significant direct effect on job satisfaction. With similar significance value of 0,000 $<0,05$, leadership has a significant direct effect on employee performance. Motivation has a significant directeffect on employee performance with significance value of $0,009<0,05$. Lastly, with the significance value of $0,008<0,05$, job satisfaction directly has a significant effect on employee performance.
\end{abstract}

Keywords: leadership performance, motivation performance, job satisfaction, employee performance, hotel employees

\section{INTRODUCTION}

Human resources are one of the important components that must be managed properly so the work produces output in accordance with what is planned. Human resources are considered the key to achieving the goals and success of the hotel. The development of hospitality is inseparable from performance, it is a must for every employee to achieve good performance so that the main goals of the hotel can be achieved. This certainly cannot be separated from the leadership and motivation factors resulting in a good job satisfaction.
The process of accomplishing work in accordance with the hotel standards is a benchmark for employees who have good performance. Performance appraisal is a useful tool not only for employees' work evaluation, but also for their development and motivation (Palinggi \& Mawardi, 2020). Employees' emotional involvement will lead to happiness and active behavior in carrying out duties and obligations given to employees. Furthermore, it will stimulate positive performance improvements and have a good impact on the achievement of work results as well as the organization (Purwadi et al., 2020).

Performance at work is related to organizational goals such as quality, efficiency, and other effectiveness criteria (Muafi \& Azim, 2019). Irwandy (2017) provides a limitation that performance is the quantity and quality of work or services provided by the work unit.

Performance details consist of internal and external data. Internal data are the information related to a person's personality. Meanwhile external data are the ones that affect human performance from the environment. Internal and external data are types of assignments that affect an individual's performance. The types of employees' assignments are action-based with several psychological consequences. In other words, individual factors can be considered as internal data and organizational work conditions as external data. In the research, work experience represents individual problems (internal) and organizational climate represents organizational working conditions (external).

Every individual is expected to find job satisfaction in their environment, which is certainly a personal matter since they have different levels of satisfaction according to the standards that apply to each of them. Many aspects of work are adapted to individual desires, which increases the level of 
perceived satisfaction.

Opinions related to job satisfaction and dissatisfaction often reflect employees' evaluations of current and past work experiences as opposed to future prospects. Thus, it can be concluded that two key factors in job satisfaction are quality of work and basic needs. Work ethic is a goal that must be achieved in accomplishing tasks. The goals are labor standards that individuals consider important and must be commensurate to meet basic needs.

Job satisfaction reflects a person's feelings about their job. It can be seen from the positive attitude of employees towards work and every element they encounter in work environment. To increase job satisfaction, the needs of employees must be responded to by the company. This has indirectly been carried out by various human resource management activities as previously described. Job satisfaction is often seen as a combination of various emotions, values, and perceptions that a person has about their tasks (Barnett, 2017).

Job satisfaction is also described as an individual expression of welfare levels related to workload and activities (Saragih, Luturlean, \& Hadiyanto, 2020). Job satisfaction is a dynamic mixture of job characteristics, environment, and personal traits and feelings depending on elements such as changes in coworkers, supervision, or organizational structure (Barnett, 2017).

Job satisfaction is a general attitude towards someone's job which shows the difference between the number of rewards received by employees and the amount they believe they should receive (Muafi \& Azim, 2019). Job satisfaction is a pleasant or unpleasant emotional state in the way employees view their work (Winarsih, Bachri, \& Yulianto, 2019).

The leader plays a key role in testing the strategy of every organization. Organizational goals can only be achieved if leaders are able to carry out their responsibilities properly. Therefore, every organization or group needs a leader who understands the leadership process. Leadership work is an attempt to guide team members to high standards and work as hard as possible. In addition, leadership work is also concerned with controlling relationships between individuals or groups in organizations. It needs to be done so that the organization is committed to achieving the right goals.

A leader must be able to establish a good personal relationship between those who are led and those who lead, so that mutual respect, mutual trust, mutual help and a sense of unity can be achieved (Muizu \& Sari, 2019). A leader must have experience, knowledge, and ability to think systematically and regularly as well as to set plans. Weak leadership can certainly hinder operational activities, whereas strong leadership encourages the achievement of subordinates and activities to achieve goals (Muafi \& Azim, 2019).

Leadership is an aspirational force, a spirit of enthusiasm, and a creative moral force, which can influence members to adjust attitudes in accordance with what the leader aspires (Syaleh, 2019). Leaders play a role in increasing abilities, commitment, skills in understanding organizational values and teamwork to improve the organization performance (Nizamuddin, Sagala, \& Napitupulu, 2018). If the leader can apply proper leadership, employees will feel satisfied which, in turn, can improve their performance (Utama \& Sari, 2019). Widodo, Sulisno, and Suryawati (2020) add that leadership is the ability to influence other people in a group to achieve certain goals.

Human resources, especially labor, need continuous motivation to do their job effectively and efficiently. Without motivation, an employee will feel less encouraged to complete tasks and easily give in to temptation. Leaders or company owners must be aware of this situation as it will gradually affect the entire organizational process, so goals might be difficult to achieve. A strong leaders' influence results in better performance. Besides, they will find it easier to deal with obstacles. On the other hand, when their influence diminishes, they will lose his performance and enthusiasm to develop good values in career.

Employees might have two motivation factors that influences them to work, namely: 1) supervisors' command and 2) self-awareness or initiative. Motivation is presented with the power that causes behavior which leads to the fulfillment of predetermined goals (Krstic et al., 2018). Saragih et al. (2020) points out another benefit from motivated employees is higher job satisfaction, while Lily et al. (2017) adds that the main strategy for increasing one's motivation is money.

Work motivation is a series of internal and external forces that cause workers to choose how to act and lead to certain behaviors (Irwandy, 2017). Motivation is often used to predict behaviors. Since it varies widely between individuals, motivation often has to be combined with abilities and environmental factors that affect employees' behaviors and performance (Lily et al., 2017).

The research aims to determine direct and indirect effects on leadership, motivation, job satisfaction and employee performance so that the research can be more complex and systematic, and capable of providing scientific answers towards problems as well as accurate solutions for the good of the future.

\section{METHODS}

The research applies a quantitative approach and a survey method with a causal model using path analysis techniques. The research aims to confirm the theoretical model with empirical data. It tries to test the hypothesis used where samples are taken from a population and questionnaires are the primary data collector. The population are 45 employees of Hotel D'Merlion Batam. Due to population limitations, all members of the population are sampled, thus the research uses a census sample. The research uses 
a questionnaire as a data collection tool and uses a Likert scale 1-5.

In quantitative research, there are two main factors that affect the quality of research data, namely: 1) the quality of research tools and 2) the quality of data collection. The quality of research tools is associated with the accuracy and reliability of materials, while the quality of data collection is the accuracy of the methods to collect data. The data are analyzed with parametric statistics using SPSS version 23.

The data analysis is conducted after data has been collected, which includes grouping data by type of respondent, sorting data for all types of respondents, producing information for each variation, counting to answer the problem plan, and counting to test the hypothesis.

Factors that need to be considered are data analysis methods, statistical methods, tests, conceptual analysis standards, and speaking when using a computer program to process data. The data analysis method is carried out after the information is analyzed. Data analysis aims to obtain a summary or interpretation of responses to the types studied based on the analysis of problematic information.

\section{RESULTS AND DISCUSSIONS}

The research instrument testing is carried out through reliability testing and validity testing with the help of SPSS 23.0 software. According to Ghozali (2017), the research instrument is declared reliable if it has a Cronbach Alpha value of 0,60, while the validity of the instrument according to Sugiyono (2017) is declared valid if the correlation coefficient of each instrument item is $\geq 0.30$. All data meet the requirements for validity and reliability. Descriptive analysis is a test based on information obtained from respondents and generated from structured data.

Table 1 explains that the leadership variable has a mean value of 36,4355 with a standard deviation of 4,17102 . The mean value of the leadership variable has a value that is higher than the minimum value of 29,00 .
This shows that the leadership of Hotel D'Merlion Batam employees needs to be evaluated from the aspect of directive leaders, supportive leaders and leaders who are oriented towards work performance.

The motivation variable has a mean value of 41,2667 with a standard deviation of 3,79832. The mean value of the motivation variable has a value that is higher than the minimum value of 26,00 . It shows that the motivation of Hotel D'Merlion Batam employees should be improved in a sense of security, competitive salary, comfortable working environment, valued work performance, and fair management attitude.

The job satisfaction variable has a mean value of 36,8000 with a standard deviation of 3,50065. The mean value of the job satisfaction variable has a value that is higher than the minimum value of 29,00 . This shows that the job satisfaction of Hotel D'Merlion Batam employees needs to be considered from the aspects of their main duties and functions, supervision, opportunities for advancement, colleagues and working conditions therein.

The employee performance variable has a mean value of 40,7778 with a standard deviation of 4,14449 . The mean value of the employee performance variable has a value that is higher than the minimum value of 22,00. It implies that the performance of Hotel D'Merlion Batam employees should be addressed in terms of the number of jobs, quantity of work, timeliness, attendance and ability to work together.

Normality testing is conducted using the Kolmogorov-Smirnov test calculation. Guidelines for decision making with the Kolmogorov-Smirnov test regarding data that are close to or normally distributed can be seen from the Asymp. Sig. (2-tailed), which is, if the Asymp Sig. (2-tailed) $>0,05$, the data distribution is normal. Meanwhile, if the Asymp. Sig. (2-tailed) < 0,05 , data distribution is not normal. The results are presented in Table 2.

Table 2 shows the Asymp. Sig. (2-tailed) in all research design groups is greater than the probability value (p) 0,05 . It can be concluded that the sample data comes from populations that are normally distributed.

Table 1 Descriptive Analysis

\begin{tabular}{lrrrr}
\hline \multicolumn{5}{c}{ Statistics } \\
\hline & $\mathbf{X}_{1}$ & \multicolumn{1}{c}{$\mathbf{X}_{2}$} & $\mathbf{Z}$ & \multicolumn{1}{c}{$\mathbf{Y}$} \\
\hline $\mathrm{N} \quad$ Valid & 45 & 45 & 45 & 45 \\
$\quad$ Missing & 0 & 0 & 0 & 0 \\
Mean & 36,4355 & 41,2667 & 36,8000 & 40,7778 \\
Median & 36,0000 & 40,0000 & 36,0000 & 41,0000 \\
Std. Deviation & 4,17102 & 3,79832 & 3,50065 & 4,14449 \\
Minimum & 29,00 & 26,00 & 29,00 & 22,00 \\
Maximum & 44,00 & 47,00 & 44,00 & 48,00 \\
\hline
\end{tabular}


Table 2 Kolmogorov-Smirnov Test

\begin{tabular}{llr}
\hline \multicolumn{2}{c}{ One-Sample Kolmogorov-Smirnov Test } \\
\hline & & Unstandardized Residual \\
\hline $\mathrm{N}$ & & 45 \\
Normal Parameters ${ }^{\mathrm{a}, \mathrm{b}}$ & Mean & $0 \mathrm{E}-7$ \\
& Std. Deviation & 1,31533513 \\
& Absolute & 0,131 \\
Most Extreme Differences & Positive & 0,100 \\
& Negative & $-0,131$ \\
Kolmogorov-Smirnov Z & & 0,880 \\
Asymp. Sig. (2-tailed) & 0,421 \\
\hline a. Test distribution is Normal & \\
b. Calculated from data & \\
\hline
\end{tabular}

Table 3 Result of Path Coefficient Analysis

\begin{tabular}{lcccc}
\hline \multicolumn{1}{c}{ Construct } & \multicolumn{2}{c}{ Coefficient } & \multicolumn{2}{c}{ Effect } \\
\hline & Beta & Sig. & Direct & Indirect \\
\hline$X_{1} \rightarrow Z$ & 0,253 & 0,082 & 0,253 & \\
$X_{2} \rightarrow Z$ & 0,574 & 0,000 & 0,574 & \\
$X_{1} \rightarrow Y$ & 0,632 & 0,000 & 0,632 & \\
$X_{2} \rightarrow Y$ & 0,213 & 0,009 & 0,213 & \\
$Z \rightarrow Y$ & 0,200 & 0,008 & 0,200 & \\
$X_{1} \rightarrow Z \rightarrow Y$ & & & & 0,050 \\
$X_{2} \rightarrow Z \rightarrow Y$ & & & & 0,114 \\
\hline
\end{tabular}

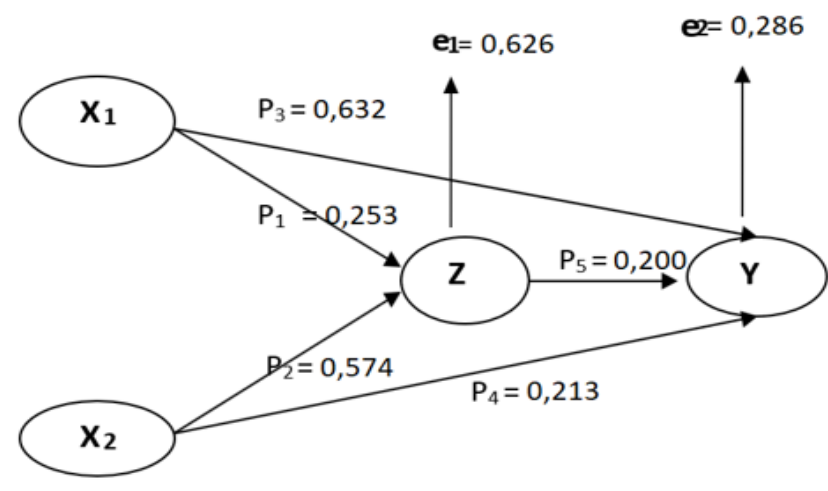

Figure 1 Hypothesis Results

Results in Table 3 and Figure 1 answer the research hypothesis. The significance value of leadership on job satisfaction is $0,082>0,05$, thus direct leadership has no significant effect on job satisfaction. The significance value of motivation on job satisfaction is $0,000<0,05$, so motivation has a significant direct effect on job satisfaction.

The significance value of leadership on performance is $0,000<0,05$, thus leadership has a significant direct effect on employee performance. The significance value of motivation on performance is $0,009<0,05$, which means motivation has a significant direct effect on employee performance. The significance value of job satisfaction on performance is $0,008<0,05$, showing that job satisfaction directly has a significant effect on employee performance. The indirect effect of leadership through job satisfaction on performance is the multiplication of the Beta value of leadership on job satisfaction with the Beta value of job satisfaction on performance, namely $0,253 \times 0,200$ $=0,050$.

The total effect given by leadership on performance coupled with the indirect effect is 0,253 $+0,050=0,682$. Based on the sum, the value of the indirect effect is smaller than the value of the direct effect, meaning that indirect leadership through job satisfaction does not have a significant effect on employee performance. The indirect effect of motivation through job satisfaction on performance is the multiplication of the Beta value of motivation on job satisfaction with the Beta value of job satisfaction on performance, which is $0,574 \times 0,200=0,114$.

The total effect given by motivation to performance coupled with the indirect effect is $0,213+0,114=0,327$. It shows that the value of the indirect effect is smaller than the value of the direct effect, meaning that indirect motivation through job satisfaction does not have a significant effect on employee performance. The output of determination $\left(\mathrm{R}^{2}\right)$ the leadership and motivation variables on job satisfaction obtains a value of 0,607 . This means that the contribution of the influence of leadership and motivation to job satisfaction is $60,7 \%$, while the remaining $39,3 \%$ is influenced by variables not studied in the research. The value of $\mathrm{e} 1$ is obtained by the formula e $1=\sqrt{ }\left(1-R^{2}\right)$, which means that e $1=\sqrt{ }$ $(1-0,607)=0,626$.

The output of determination $\left(\mathrm{R}^{2}\right)$ the variable leadership, motivation and job satisfaction on employee performance obtains a value of 0,918 . It shows that the contribution of the influence of leadership, motivation and job satisfaction on employee performance is $91,8 \%$, while the remaining $8,2 \%$ is influenced by other variables. The value of e 2 is obtained by the formula e2 $=\sqrt{ }\left(1-R^{2}\right)$, which results in e2 $=\sqrt{ }(1-$ 
$0,918)=0,286$.

Leaders can provide clarity to employees, input from subordinates can be absorbed and considered for making a decision. The enthusiasm or encouragement given by the leader can contribute to effective and productive performance. It is concluded that better leadership allows employees to develop and improve performance.

Employees feel a balance in doing work from what they are responsible for. Employees have the same opportunity to make career leaps so that performance by itself will reach a good standard. With a good management, it certainly is an advantage for employees to be able to show good performance. It is believed that higher level of employee job satisfaction leads to a more productive performance.

Employees have some motivations at work, namely: 1) fairness in the distribution of salaries, 2) reward from the company for achieving good performance, and 3) certainty in security at work. All of this will certainly increase positive values in encouraging employees to be more active, practical, tactical, innovative, and creative. It can be concluded that higher motivation allows employees to show better performance.

Leaders could provide clarity to employees, where input from subordinates should be considered to make decisions. The enthusiasm or encouragement given by the leader can contribute to effective and productive performance. Continuity of leadership in responding to the desires of subordinates is a continuous flow of motivation to employees, so these factors can create a stable performance at Hotel D'Merlion Batam.

Employees should feel balanced in doing work according to their responsibilities. They have the same opportunity to take a career leap so that performance by itself will reach a good standard. Leaders that regularly monitors employee movements would certainly provide an advantage for employees to show good performance. It is concluded that higher level of employee job satisfaction will encourage them to be more productive.

\section{CONCLUSIONS}

The research finally comes up with conclusions. Leadership does not directly have a significant effect on job satisfaction. Motivation has a direct effect on job satisfaction. Leadership, motivation, and job satisfaction have a significant direct effect on employee performance. Leadership and motivation through job satisfaction have no effect on employee performance.

Human resources must be managed properly, so the work produces output in accordance with workplans since human resources are the key to achieving the goals and success of the hotel. The development of hospitality is inseparable from performance as it is essential for every employee to achieve good performance, so main goals of the hotel can be achieved. This certainly cannot be separated from the leadership and motivation factors resulting in good job satisfaction.

Leaders must pay attention to aspects of leadership, motivation, and job satisfaction since they affect employees' performance. It is essential for leaders must have intelligence and the ability to build relationships between employees. This will create credible employee attitudes in handling assigned tasks and responsibilities, create positive behavior such as ethics, good morals so that remarkable performance can be achieved.

The organizational performance model will involve aspects of leadership, motivation, in developing oriented concepts and incentives that have a direct effect on employee performance. Better leadership and employees' motivation may result in higher level of perceived satisfaction, which encourages a more consistent direction of employees' performance.

The research has limitations since it only examines Hotel D'Merlion Batam, whereas there are many other hotels in Batam. Furthermore, the research has limited variables, while there are many other variables that can be examined further. It is suggested that future research expand the scope so that employee performance can be measured with more variables that has not discussed. Future researchers may provide alternative solutions that are relevant and complex with scientific standards.

\section{REFERENCES}

Barnett, D. (2017). Leadership and job satisfaction: Adjunct faculty at a for-profit university. International Journal of Psychology and Educational Studies, 4(3), 53-63. https://doi.org/10.17220/ijpes.2017.03.006.

Ghozali, I. (2017). Aplikasi Analisis Multivariate dengan Program SPSS. Semarang: Badan Penerbit Universitas Diponegoro

Irwandy. (2017). The effect of leadership style, work climate and work motivation on job performance at State University of Medan. International Journal of Education and Research, 5(8), 103-112. https:// www.ijern.com/journal/2017/August-2017/10.pdf.

Krstic, M., Obradovic, V., Terzic-Supic, Z., Stanisavljevic, D., \& Todorovic, J. (2018). Motivational factors of employees in health-care institutions in Serbia. Management: Journal of Sustainable Business and Management Solutions in Emerging Economies, 24(1), 33-43. https://doi.org/10.7595/management. fon. 2018.0022 .

Lily, Ginting, P., Lumbanraja, P., \& Siahaan, E. (2017). The antecedent of work motivation and the effect on the performance of civil servants with job satisfaction as moderating variable (A study of civil servants on West Coast, North Sumatra - Indonesia). International Journal of Economic Research, 14(8), 161-176. https://www.researchgate.net/ publication/319007690_The_antecedent_of_work motivation_and_the_effect_on_the_performance 
of_civil_servants_with_job_satisfaction_as moderating_variable_A_study_of_civil_servants_ on_West_Coast_North_Sumatra_-_Indonesia.

Muafi \& Āzim, $\bar{M}$. (2019). The effect of servant leadership, organizational culture in employee performance mediated by job satisfaction (Study case of Al-Kahfi Islamic Boarding School, Somalangun, Kebumen). Proceedings on Engineering Sciences, 1(2), 143162. https://doi.org/10.24874/pes01.02.014.

Muizu, W. O. Z. \& Sari, D. (2019). Improving employee performance through organizational culture, leadership, and work motivation: Survey on banking organizations in Southeast Sulawesi. Jurnal Bisnis dan Manajemen, 20(1), 71-88. https://doi. org/10.24198/jbm.v20i1.266.

Nizamuddin, Sagala, S., \& Napitupulu, E. (2018). Effect of leadership, organizational structure, compensation, and motivation toward performance of aggregat data control on the statistics centre of North Sumatra province. International Journal of Education and Research, 6(1), 167-180. https://www.ijern.com/ journal/2018/January-2018/15.pdf.

Palinggi, Y. \& Mawardi. (2020). The effect of headmaster leadership style towards vocational high school teachers' work satisfaction, work motivation and performance in East Kalimantan, Indonesia. Russian Journal of Agricultural and Socio-Economic Sciences, 102(6), 117-124. https://doi.org/10.18551/ rjoas.2020-06.14.

Purwadi, Darma, D. C., Febrianti, W., \& Mirwansyah, D. (2020). Exploration of leadership, organizational culture, job satisfaction, and employee performance. Technium Social Sciences Journal, 6(1), 116-130. https://doi.org/10.47577/tssj.v6i1.242.
Saragih, R., Luturlean, B. S., \& Hadiyanto, F. (2020). Employee job satisfaction in mediating the relationship between work motivation and affective commitment in roof tile industry. Jurnal Bisnis dan Manajemen, 21(1), 16-26. https://doi.org/10.24198/ jbm.v21i1.346.

Sugiyono. (2017). Metode Penelitian Bisnis. Bandung: CV Alfabeta.

Syaleh, H. (2019). Pengaruh kepemimpinan dan motivasi terhadap kinerja pegawai Dinas Prasarana Jalan dan Jembatan Wilayah Bukittinggi. Jurnal Benefita, 4(2), 221-232. http://doi.org/10.22216/jbe.v4i2.2697.

Utama, M. D. P. \& Sari, M. M. R. (2019). Pengaruh kepemimpinan, kompensasi dan laba pada kepuasan kerja karyawan PT. Bank Bukopin Tbk. Cabang Denpasar. E-Jurnal Akuntansi, 29(1), 437-450. https://doi.org/10.24843/eja.2019.v29.i01.p28.

Widodo, P., Sulisno, M., \& Suryawati, C. (2020). Pengaruh penerapan perilaku syariah dalam pelayanan keperawatan, beban kerja, dan kepemimpinan terhadap kepuasan kerja perawat di rumah sakit. LINK, 16(2), 23-30. https://doi.org/10.31983/link. v16i1.5596.

Winarsih, S., Bachri, A. A., \& Yulianto, A. (2019). Pengaruh motivasi dan kepuasan kerja terhadap kinerja karyawan (Studi pada Bank Kalsel Syariah Kandangan). JWM (Jurnal Wawasan Manajemen), 6(2), 197-208. https://doi.org/10.20527/jwm. v6i2.153. 